\title{
In silico analysis of alpha1-antitrypsin variants: The effects of a novel mutation
}

\author{
Sabri Denden ${ }^{1}$, Nadia Leban ${ }^{1}$, Donia Hayek ${ }^{1}$, Jalel Knani ${ }^{2}$, Jemni Ben Chibani ${ }^{1}$ and Amel Haj Khelil ${ }^{1}$ \\ ${ }^{1}$ Biochemistry and Molecular Biology Laboratory, Faculty of Pharmacy, Monastir, Tunisia. \\ ${ }^{2}$ Pulmonology Department, CHU Tahar Sfar, Mahdia, Tunisia.
}

\begin{abstract}
Alpha1-antitrypsin (AAT) is a highly polymorphic protein with more than 120 variants that are classified as normal (normal protein secretion), deficient (reduced circulating AAT level caused by defective secretion) or null (no protein secretion). Alpha1-antitrypsin deficiency, one of the most common genetic disorders, predisposes adults to pulmonary emphysema and, to a lesser extent, chronic liver disease and cirrhosis. In this report, we provide additional sequence data for alpha1-antitrypsin based on the characterization of a novel variant detected in a 53-year-old heterozygous patient with chronic obstructive pulmonary disease. The mutation occurred on a $\mathrm{Pl}^{\star} \mathrm{M} 2$ base allele and was characterized by a $T \rightarrow C$ transition at nt 97 in exon II that led to the replacement of phenylalanine by leucine (F33L). Since the mutation was found in the heterozygous state with the expression of a normally secreted variant (PI*M1) it was not possible to assess the pattern of F33L secretion. However, computational analyses based on evolutionary, structural and functional information indicated a reduction of $23 \AA^{3}$ in the side chain volume and the creation of a cavity in the protein hydrophobic core that likely disturbed the tridimensional structure and folding of AAT. The accuracy of the in silico prediction was confirmed by testing known mutations.
\end{abstract}

Key words: alpha1-antitrypsin, computational analysis, damaging mutation.

Received: February 19, 2010; Accepted: June 2, 2010.

Alpha1-antitrypsin (AAT) is the archetypal protein of the serine proteinase inhibitor (SERPIN) superfamily. AAT is synthesized in hepatocytes and macrophages and protects the lower respiratory tract from proteolytic degradation by neutrophil elastase (Perlino et al., 1987). This protein is encoded by a highly polymorphic locus, PI (for Proteinase Inhibitor), that consists of seven exons dispersed over 12.2 kb on chromosome 14q31-32.3 (Li et al., 1998). The two parental PI genes are codominantly expressed and dictate the AAT serum level (Brantly et al., 1991). The most common PI allele is designated PI*M and has a gene frequency of 0.95 . Homozygosity of the PI*M allele results in AAT plasma concentrations ranging from 150 to $350 \mathrm{mg} / \mathrm{dL}$, which provides a sufficient protease/antiprotease balance to protect lung tissues. The most frequent deficient variants are PI*S (p.E264V) and PI*Z (p.E342L). $\mathrm{PI} * \mathrm{~S}$ produces approximately $60 \%$ of $\mathrm{PI} * \mathrm{M}$ alpha1-antitrypsin and the $\mathrm{PI}^{*} \mathrm{Z}$ allele produces $10 \%-15 \%$ of normal AAT levels. Other rarer deficiency states arising from null alleles result in no detectable AAT protein (Crystal, 1990). The major clinical consequence of AAT deficiency (AATD) is a high risk of early onset panlobular emphy-

Send correspondence to Amel Haj Khelil. Biochemistry and Molecular Biology Laboratory, Faculty of Pharmacy, 1, Av. Avicenne, 5019 Monastir, Tunisia. E-mail: Amel.HK@fsm.rnu.tn sema and, to a lesser extent, chronic liver disease and cirrhosis (Mahadeva and Lomas, 1998). Current gene frequency data indicate that AATD is one of the most common inherited disorders worldwide (de Serres et al., 2007).

In this report, we provide additional sequence data for AAT based on the characterization of a novel AAT mutation discovered in a Tunisian patient with chronic obstructive pulmonary disease (COPD).

A 53-year-old man diagnosed with pulmonary emphysema was enrolled in a targeted AATD screening program run by the Pneumology Department of Ibn Eljazzar Hospital in Kairouan (central Tunisia). Based on a previously described algorithm (Denden et al., 2009), all patients with obstructive lung disease and an AAT level $<150 \mathrm{mg} / \mathrm{dL}$ (threshold value) attended at this unit are screened for AATD. In this case, the AAT plasma concentration was $132 \mathrm{mg} / \mathrm{dL}$, as measured using an immune turbidimetric assay (Denden et al., 2009). The patient, an ex-smoker with a history of 28 pack-years, presented the common symptoms of airway obstructive disease, i.e., breathlessness, cough, wheeze and phlegm. These symptoms began at 50 years of age. During a two-year follow-up, the patient showed increasing dyspnea and weight loss. An intradermal skin test and the quantification of total $\operatorname{IgE}(22.5 \mathrm{IU} / \mathrm{mL})$ indicated that there was no atopy. At his first presentation, chest radiographs showed hyperinflation 
with an anterior diaphragmatic angle of 107 degrees in lateral view and a retrosternal airspace of $5.2 \mathrm{~cm}$. Decreased lung markings and bullae were localized in the lower zones. Chest computed axial tomography confirmed the emphysematous state of the lower lobe and the presence of pulmonary parenchymal destruction seen as large areas of hypolucency and the presence of bullae. Baseline lung function tests were consistent with the onset of severe COPD: the forced expiratory volume in $1 \mathrm{~s} \mathrm{(FEV1)} \mathrm{was} 28 \%$ of the predicted value and the FEV1/FVC (forced vital capacity) ratio was $70 \%$. After bronchodilator inhalation, the FEV1 improved $4.8 \%$ relative to the baseline value. During the follow-up, lung function impairment, assigned by the annual decline in FEV1 ( $\triangle \mathrm{FEV} 1)$, was $213 \mathrm{~mL} /$ year.

Blood samples were collected for analysis after obtaining the patients informed consent and the investigation was approved by the local Ethics Committees of the institutions involved. DNA was isolated from whole peripheral blood using a standard phenol-chloroform method. Genotyping by RFLP-PCR was used to detect the most prevalent AATD mutations (S and Z) (Denden et al., 2009). This analysis does not report any $\mathrm{S}$ or Z AAT allele. Sequencing of the AAT gene coding regions as previously described (Denden et al., 2009) revealed a novel point mutation at c. $97 \mathrm{~T} \rightarrow \mathrm{C}$ (Figure 1). This substitution led to the replacement of phenylalanine by leucine (F33L). Since the mutation was found in the heterozygous state, the PCR product of exon II of the SERPINA1 gene was cloned to identify the allele with the mutated base. Cloning was done using a
TOPO-TA cloning kit (Invitrogen Corporation, Carlsbad, CA). The sequencing of positive clones confirmed the presence of the c.97 $\mathrm{T} \rightarrow \mathrm{C}$ point mutation on the $\mathrm{PI}{ }^{*} \mathrm{M} 2$ (c.302 $\mathrm{G} \rightarrow \mathrm{A}$ ) allele (Figure 2).

Although the mutation occurred in the heterozygous state, mild AATD, usually observed in subjects carrying only one deficient allele, could explain the disease. Indeed, a meta-analysis of previous studies indicated an increase in the risk of COPD in PI*MZ heterozygotes (Hersh et al., 2004). The serum AAT level in this patient $(132 \mathrm{mg} / \mathrm{dL})$ was within the normal AAT range of the Tunisian population [120-280 mg/dL] (Denden et al., 2008). However, the patient's heterozygous state meant that the expression of a normal allele (PI*M1) could have masked any deficiency arising from the mutated allele. Additional investigations were needed to elucidate this deficiency but, unfortunately, none of the patient's family members was available for further study.

To circumvent this limitation, computational methods were used to assess whether the mutation was detrimental to the protein structure and/or function. Changes in the stability of the mutant protein compared to the wild type protein were predicted using the Auto-Mute server (Masso and Vaisman, 2008). SIFT (Sorting Intolerant from Tolerant) software (Ng and Henikoff, 2002) was used to predict tolerance to the causal non-synonymous SNP (nsSNP) on the basis of sequence conservation in the protein family. The PolyPhen bioinformatic algorithm (Ramensky et al., 2002) was used to predict the influence of the mutation

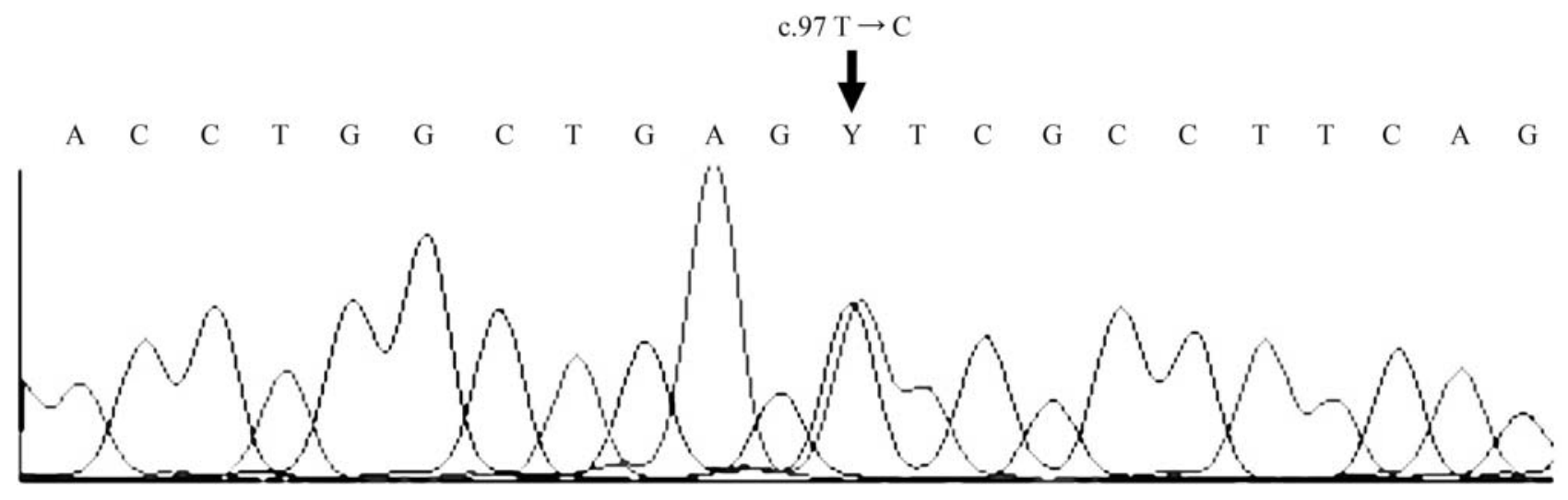

Figure 1 - Partial exon II sequence of the SERPINA1 gene (genomic DNA) reveals a novel c.97 T $\rightarrow$ C mutation at the heterozygous state.

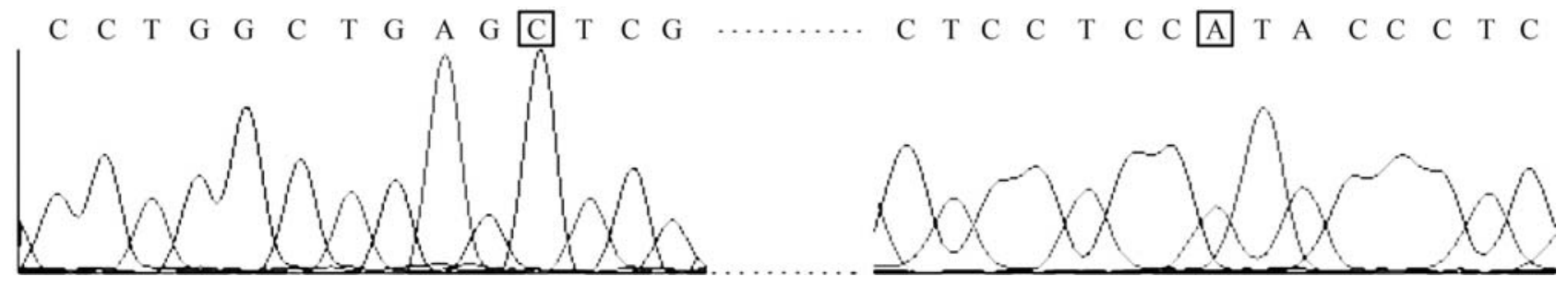

Figure 2 - Partial exon II sequence of the SERPINA1 gene (cloned DNA) reveals the presence of c.97 T $\rightarrow$ C and c.302 G $\rightarrow$ A substitutions on the same chromosome. 
based on data derived from structural parameters, functional annotations and evolutionary information, and the HybridMeth algorithm (Capriotti et al., 2006) was used to predict the effect of the nsSNP based on evolutionary information. The p.F33L mutant was predicted to be $1.41 \mathrm{kcal}$ $\mathrm{mol}^{-1}$ less stable than the wild type protein (PDB ID: 1atu). SIFT software showed that the phenylalanine at position 33 was highly conserved in the protein family (score of 0.00 ), while the HybridMeth algorithm favored a disease-associated nsSNP with a reliability index of 7. PolyPhen predicted that the p.F33L mutation was possibly deleterious to AAT (PSIC score difference of 1.882). The PolyPhen decision tree indicated that substitution of the buried amino acid $\mathrm{F}$ by $\mathrm{L}$ at position 33 in the AAT-A- $\alpha$-helix led to a reduction in side chain volume of $23 \AA^{3}$ and the creation of a cavity. Cavities in the protein hydrophobic core are very likely to disturb the tridimensional structure and folding of AAT. In silico analysis with known mutations was used to assess the accuracy of the predictions and confirmed that the com- putational analyses based on evolutionary, structural and functional information were in agreement with previous findings in vivo and in vitro (Table 1). A neutral effect was predicted for mutations associated with a normal AAT level: the common AAT mutations PI*M2 (R101H) and PI*M3 (E376D) apparently had no effect on the protein (Table 1). Mutations associated with a low AAT level were predicted to be damaging: AATD, observed in the most prevalent deficiency variants $\mathrm{PI} * \mathrm{~S}(\mathrm{E} 264 \mathrm{~V})$ and $\mathrm{PI} * \mathrm{Z}$ (E342L), was attributed to a change in hydrophobicity and charge at buried sites of the protein. The rare allele PI* $\mathrm{M}_{\text {wurzburg }}$ (E369S) showed the same abnormality as the F33L mutation, i.e., a $23 \AA^{3}$ reduction in side chain volume (Table 1).

In conclusion, we have described a novel rare PI mutation that is likely to be clinically important, as suggested by computational analyses. Further studies are required to confirm this finding.

Table 1 - Computational analysis of alpha1-antitrypsin variants.

\begin{tabular}{|c|c|c|c|c|c|c|c|}
\hline \multirow[t]{2}{*}{ Mutation } & \multirow[t]{2}{*}{ Location } & \multirow{2}{*}{$\begin{array}{c}\text { Auto-mute } \\
\Delta \Delta \mathrm{G} \text { expected }\end{array}$} & \multirow{2}{*}{$\begin{array}{c}\text { SIFT } \\
\text { Tolerance (score) }\end{array}$} & \multirow{2}{*}{$\begin{array}{l}\text { HybridMeth } \\
\text { SPBP (RI) }\end{array}$} & \multicolumn{3}{|r|}{ PolyPhen } \\
\hline & & & & & $\begin{array}{l}\text { PSIC dif- } \\
\text { ference }\end{array}$ & $\begin{array}{c}\text { Substitution } \\
\text { prediction }\end{array}$ & Substitution effect \\
\hline \multicolumn{8}{|c|}{ Normally secreted variants } \\
\hline $\mathrm{R} 101 \mathrm{H}$ & $\mathrm{hD}$ & -0.29 & Yes $(0.47)$ & Neutral (6) & 1.162 & benign & NA \\
\hline E376D & s4B & -0.17 & Yes $(0.56)$ & Neutral (7) & 0.264 & benign & $\begin{array}{l}\text { Hydrophobicity change at buried site of } 0.78 \text {; } \\
\text { accN: } 0.00\end{array}$ \\
\hline A34T & hA & -2.17 & Yes $(0.06)$ & Neutral (4) & 0.657 & benign & Distance to MET 385 of $3.345 \AA$ \\
\hline P88T & $\mathrm{hD}$ & -1.32 & Yes $(0.59)$ & Neutral (2) & 0.937 & benign & NA \\
\hline A60T & $\mathrm{hB}-\mathrm{hC}$ & -1.35 & No $(0.02)$ & Neutral (7) & 1.001 & benign & NA \\
\hline G148R & $\mathrm{s} 1 \mathrm{~A}$ & -1.14 & Yes $(0.64)$ & Neutral (3) & 0.631 & benign & Charge change at exposed site, accN: 0.83 \\
\hline E204K & $\mathrm{s} 4 \mathrm{C}$ & -0.89 & Yes $(0.98)$ & Neutral (3) & 0.134 & benign & NA \\
\hline L276P & $\mathrm{hH}$ & -2.22 & Yes $(0.27)$ & Disease (5) & 0.931 & benign & Distance to ILE $375 \mathrm{~B}$ of $3.807 \AA$ \\
\hline $\mathrm{P} 362 \mathrm{~T}$ & s1C & -1.45 & Yes $(0.52)$ & Neutral (8) & 1.411 & benign & NA \\
\hline \multicolumn{8}{|c|}{ AAT Deficient variants } \\
\hline E342L & $\mathrm{s} 5 \mathrm{~A}$ & 0.87 & No $(0.00)$ & Disease (7) & 3.190 & $\begin{array}{l}\text { probably } \\
\text { damaging }\end{array}$ & $\begin{array}{l}\text { Hydrophobicity change at buried site of } \\
1.59 \text {, accN: } 0.03 \text {; charge change at buried site }\end{array}$ \\
\hline E264V & hG & 0.32 & No $(0.03)$ & Disease (4) & 1.773 & $\begin{array}{l}\text { probably } \\
\text { damaging }\end{array}$ & $\begin{array}{l}\text { Hydrophobicity change at buried site of } 1.48 \text {; } \\
\text { LYS } 383 \mathrm{H} \text { distance } 2.658 \AA \text {; charge change at } \\
\text { buried site, accN: } 0.03\end{array}$ \\
\hline $\mathrm{R} 223 \mathrm{C}$ & thIs5 A & -1.18 & No $(0.04)$ & Disease (3) & 0.671 & $\begin{array}{l}\text { possibly } \\
\text { damaging }\end{array}$ & $\begin{array}{l}\text { Cavity creation at buried site of }-65 \AA^{3} \text {; ligand: } \\
\text { CIT distance } 3.818 \AA \text {; hydrophobicity change } \\
\text { at buried site of } 1.66 \text {; charge change at buried } \\
\text { site, accN: } 0.15\end{array}$ \\
\hline L41P & $\mathrm{hA}$ & -1.67 & No $(0.00)$ & Disease (8) & 2.621 & $\begin{array}{l}\text { probably } \\
\text { damaging }\end{array}$ & $\begin{array}{l}\text { Hydrophobicity change at buried site of } \\
1.07 \text {, accN: } 0.05\end{array}$ \\
\hline $\mathrm{K} 335 \mathrm{E}$ & $\mathrm{s} 5 \mathrm{~A}$ & -0.17 & No $(0.00)$ & Disease (5) & 1.612 & $\begin{array}{l}\text { possibly } \\
\text { damaging }\end{array}$ & Distance to PHE 384B of $5.913 \AA$ \\
\hline M221T & s4C-s2B & -2.33 & No $(0.00)$ & Disease (6) & 3.746 & $\begin{array}{l}\text { probably } \\
\text { damaging }\end{array}$ & $\begin{array}{l}\text { Hydrophobicity change at buried site of } \\
1.02 \text {, accN: } 0.00\end{array}$ \\
\hline $\mathrm{T} 85 \mathrm{M}$ & $\mathrm{hC}-\mathrm{hD}$ & 0.07 & Yes $(0.09)$ & Disease (4) & 2.400 & $\begin{array}{l}\text { probably } \\
\text { damaging }\end{array}$ & Overpacking of $47 \AA^{3}$, accN:0.90 \\
\hline $\mathrm{R} 39 \mathrm{C}$ & $\mathrm{hA}$ & -0.86 & No $(0.00)$ & Disease (7) & 2.872 & $\begin{array}{l}\text { probably } \\
\text { damaging }\end{array}$ & $\begin{array}{l}\text { Cavity creation at buried site of }-65 \AA^{3} \text {, accN: } \\
0.35\end{array}$ \\
\hline
\end{tabular}


Table 1 (cont.)

\begin{tabular}{|c|c|c|c|c|c|c|c|}
\hline \multirow[t]{2}{*}{ Mutation } & \multirow[t]{2}{*}{ Location } & \multirow{2}{*}{$\begin{array}{c}\text { Auto-mute } \\
\Delta \Delta \mathrm{G} \text { expected }\end{array}$} & \multirow{2}{*}{$\begin{array}{c}\text { SIFT } \\
\text { Tolerance (score) }\end{array}$} & \multirow{2}{*}{$\begin{array}{l}\text { HybridMeth } \\
\text { SPBP (RI) }\end{array}$} & \multicolumn{3}{|r|}{ PolyPhen } \\
\hline & & & & & $\begin{array}{l}\text { PSIC dif- } \\
\text { ference }\end{array}$ & $\begin{array}{l}\text { Substitution } \\
\text { prediction }\end{array}$ & Substitution effect \\
\hline P369S & s4B & -1.61 & No $(0.00)$ & Disease (3) & 1.726 & $\begin{array}{l}\text { possibly } \\
\text { damaging }\end{array}$ & $\begin{array}{l}\text { Cavity creation at buried site of }-23 \AA^{3} \text {, accN: } \\
0.20\end{array}$ \\
\hline P369L & s4B & -1.65 & No $(0.00)$ & Disease (5) & 3.230 & $\begin{array}{l}\text { probably } \\
\text { damaging }\end{array}$ & Overpacking of $55 \AA^{3}$, accN: 0.20 \\
\hline $\mathrm{D} 256 \mathrm{~V}$ & $\begin{array}{c}\text { ts2Bs3B- } \\
\text { hG }\end{array}$ & 0.53 & Yes $(0.11)$ & Disease (5) & 1.698 & $\begin{array}{c}\text { possibly } \\
\text { damaging }\end{array}$ & $\begin{array}{l}\text { Distance to functional site SER } 232 \mathrm{~A} \text { of } 5.173 \\
\AA \text {; distance to LYS } 368 \mathrm{~B} \text { of } 3.307 \AA\end{array}$ \\
\hline G67E & $\mathrm{hB}-\mathrm{hC}$ & -1.02 & No $(0.00)$ & Disease (8) & 2.760 & $\begin{array}{l}\text { probably } \\
\text { damaging }\end{array}$ & $\begin{array}{l}\text { Overpacking at buried site of } 78 \AA^{3} \text {; } \\
\text { hydrophobicity change at buried site of } 2.44 \text {; } \\
\text { Charge change at buried site, accN: } 0.00\end{array}$ \\
\hline A336T & $\mathrm{s} 5 \mathrm{~A}$ & -0.26 & Yes $(0.08)$ & Disease (2) & 0.993 & $\begin{array}{l}\text { probably } \\
\text { damaging }\end{array}$ & $\begin{array}{l}\text { Hydrophobicity change at buried site of } 1.08 \text {; } \\
\text { distance to PHE 384B of } 4.320 \AA \text {, accN: } 0.00\end{array}$ \\
\hline G225R & s4C-s2B & -0.48 & Yes $(0.11)$ & Disease (2) & 0.714 & $\begin{array}{l}\text { probably } \\
\text { damaging }\end{array}$ & $\begin{array}{l}\text { Overpacking at buried site of } 133 \AA^{3} \text {; PRO } \\
\text { 361B distance } 5.919 \AA \text {; hydrophobicity change } \\
\text { at buried site of } 3.3 \text {; charge change of a buried } \\
\text { site, accN: } 0.00\end{array}$ \\
\hline F33L & hA & -1.41 & No $(0.00)$ & Disease (7) & 1.882 & $\begin{array}{c}\text { possibly } \\
\text { damaging }\end{array}$ & $\begin{array}{l}\text { Cavity creation at buried site of }-23 \AA^{3} \text {, accN: } \\
0.00\end{array}$ \\
\hline
\end{tabular}

$\Delta \Delta \mathrm{G}$ expected: free energy change of protein stability at $25^{\circ} \mathrm{C}, \mathrm{pH} 7\left(\mathrm{kcal} \mathrm{mol}{ }^{-1}\right)$ computed using the Auto-Mute server; Tolerance: tolerance to substitution scored using SIFT software; SPBP: sequence and profile based prediction of HybridMeth; RI: reliability index. PSIC difference: Position-Specific Independent Counts score difference between the two amino acids determined using the PolyPhen tool; accN: normed accessible surface area.

\section{Acknowledgments}

The authors thank Dr. Maurizio Luisetti of the Center for Diagnosis of Inherited Alpha1-Antirtypsin Deficiency, Pavia, Italy, for providing laboratory space for Sabri Denden to clone and sequence the AAT variant described in this work.

\section{References}

Brantly ML, Wittes JT, Vogelmeier CF, Hubbard RC, Fells GA and Crystal RG (1991) Use of a highly purified alpha 1 antitrypsin standard to establish ranges for the common normal and deficient alpha 1 antitrypsin phenotypes. Chest 100:703-708.

Capriotti E, Calabrese R and Casadio R (2006) Predicting the insurgence of human genetic diseases associated to single point protein mutations with support vector machines and evolutionary information. Bioinformatics 22:2729-2734.

Crystal RG (1990) a 1-antitrypsin deficiency, emphysema, and liver disease genetic basis and strategies for therapy. J Clin Invest 85:1343-1352.

de Serres FJ, Blanco I and Fernández-Bustillo E (2007) PI S and PI Z alpha-1 antitrypsin deficiency worldwide. A review of existing genetic epidemiological data. Monaldi Arch Chest Dis 67:184-208.

Denden S, Haj Khelil A, Perrin P, Daimi H, Leban N, Ouaja A, Mahodouani K, Hlioui L, Lefranc G and Ben Chibani J (2008) Alpha 1 antitrypsin polymorphism in the Tunisian population with special reference to pulmonary disease. Pathol Biol 56:106-110.
Denden S, Zorzetto M, Amri F, Knani J, Ottaviani S, Scabini R, Gorrini M, Ferrarotti I, Campo I, Ben Chibani J et al. (2009) Screening for alpha 1 antitrypsin deficiency in Tunisian subjects with obstructive lung disease: A feasibility report. Orphanet J Rare Dis 4:12.

Hersh CP, Dahl M, Ly NP, Berkey CS, Nordestgaard BG and Silverman EK (2004) Chronic obstructive pulmonary disease in alpha 1-antitrypsin PI MZ heterozygotes: A metaanalysis. Thorax 59:843-849.

Li Y, Zhou L, Twining SS, Sugar J and Yue BYJT (1998) Involvement of Sp1 elements in the promoter activity of the alpha 1 proteinase inhibitor gene. J Biol Chem 273:9959-9965.

Mahadeva R and Lomas DA (1998) Genetics and respiratory disease. 2: Alpha 1-antitrypsin deficiency, cirrhosis and emphysema. Thorax 53:501-505.

Masso M and Vaisman I (2008) Accurate prediction of stability changes in protein mutants by combining machine learning with structure based computational mutagenesis. Bioinformatics 24:2002-2009.

Ng PC and Henikoff S (2002) Accounting for human polymorphisms predicted to affect protein function. Genome Res 12:436-446.

Perlino E, Cortese R and Ciliberto G (1987) The human alpha 1 -antitrypsin gene is transcribed from two different promoters in macrophages and hepatocytes. EMBO J 6:2767-2771.

Ramensky V, Bork P and Sunyeav S (2002) Human non synonymous SNPs: Server and survey. Nucleic Acids Res 30:3894-3900.

\section{Associate Editor: Carlos F.M. Menck}

License information: This is an open-access article distributed under the terms of the Creative Commons Attribution License, which permits unrestricted use, distribution, and reproduction in any medium, provided the original work is properly cited. 